\title{
PEMBELAJARAN BAHASA INDONESIA MAU DIBAWA KE MANA?
}

\author{
Hanna \\ Guru Besar Psikolinguistik dan Kependidikan \\ Universitas Haluoleo, Kepala LPMP Sulawesi Tenggara
}

\begin{abstract}
Abstrak
Tulisan ini diilhami oleh dua orang pakar bahasa yakni pakar dialektologi Prof. Mahsun, mencoba menawarkan fase pembelajaran bahasa sedangkan pakar linguistik fungsional Prof. Amrin Saragih menawarkan pentingnya linguistik fungsional. Makalah ini menawarkan kepada kita tentang konsep pembelajaran bahasa untuk mewujudkan tujuan pendidikan yakni pembentukan karakter yang terwujud dalam kesatuan esensial si subyek dengan bahasa dan perilaku serta sikap hidup yang dimilikinya dengan mengacu pada teori Foerster. Bagi Foerster, karakter merupakan sesuatu yang mengualifikasi seorang pribadi. Karakter menjadi identitas yang mengatasi pengalaman kontingen yang selalu berubah. Dari kematangan karakter inilah, kualitas seorang pribadi diukur.
\end{abstract}

Kata Kunci: pembelajaran bahasa, pembentukan karakter, kualitas pribadi

\begin{abstract}
This article was inspired by two expert linguists on the dialectology Mahsun, try to offer language learning phase while the functional linguistic expert Amrin Saragih offer important functional linguistics. This paper offers us about the concept of language learning to achieve the educational goals embodied in the character building of the essential unity of the subject with the language and the behavior and attirudes of its life with reference to the Foerster theory. For Foerster, the character is something to qualify the person. The characters become contingent identity that transcends experience that always berubah. Dari marurity of this character, the quality of a person is measured.
\end{abstract}

Keywords: language learning, character building, person quality

\section{PENDAHULUAN}

Suatu hal yang tak dapat dipungkiri bahwa peristiwa yang teramat penting yang menyangkut kehidupan berbangsa dan bernegara adalah peristiwa yang terjadi pada 28 Oktober 1928, vang dikenal dengan nama Sumpah Pemuda. Sumpah Pemuda yang merupakan pernyataan kebulatan tekad itu dimaknai dengan tiga unsur ma yang saling kaitmengait satu sama lain. Ketiga unsur itu adalah pertama, pengakuan terhadap kesatuan, kedua adalah kedaulatan terhadap tanah air dan bangsa, dan ketiga adalah unsur pernyataan tekad bahwa bahasa Indonesia adalah bahasa persatuan bangsa Indonesia.

Kita dapat membayangkan apa yang akan terjadi, jika tidak ada bahasa Indonesia yang dapat mempersatukan berbagai suku bangsa di Indonesia yang hadir dengan berbagai macam bahasa dan budaya yang satu sama lain memperlihatkan keberbedaannya. Di tengah porak 
porandanya tatanan sosial kehidupan bernegara, sebagai dampak runtuhnya rezim Orde Baru, bahasa nasional kita masih mampu memperlihatkan peran pemersatunya. Coba kita bayangkan bagaimana mengajak saudara-saudara kita yang hendak memisahkan diri dari NKRI: seperti Aceh, Papua, Maluku bersatu tanpa kesamaan bahasa yang kita gunakan untuk mengomunikasikan ide kebersatuan itu sendiri.

Sudah cukup banyak bukti yang memperlihatkan pada kita bagaimana bahasa memainkan peran yang sangat penting dalam kehidupan suatu komunitas bangsa. Abad ke-20 telah ditandai dengan terjadinya banyak konflik etnik yang didasari penentuan hak-hak bahasa asli. Seperti isu etnik lainnya, perbedaan bahasa tidak dapat dibiarkan begitu saja. Kasus konflik etnik yang berujung pada eksodusnya sebagian besar minoritas Turki ketika pemerintah komunis Bulgaria tahun 1970 mencoba membangun kekuatan Bulgarisasi dengan mengambil nama Turki dan muslim merupakan contoh persoalan bahasa ikut bermain dalam membina tatanan kehidupan yang harmoni. Kasus lain, misalnya Latvia yang sejak kemerdekaannya 1991, menghadapi persoalan berupa kebutuhan untuk memperkenalkan kembali bahasa Latvia sebagai bahasa negara dan bahasa pengan tar perhubungan kemasyarakatan di samping memberi hak hidup bagi bahasabahasa minoritas, kelompok etnis kecil serta dengan tidak mengurangi hak hidup bahasa Rusia yang sejak 1988 menjadi bahasa yang dominan yang mengambil alih bahasa Latvia. Untuk memperbaiki kondisi itu tahun 1989 bahasa Latvia ditetapkan sebagai bahasa resmi kenegaraan dan secara bertahap mulai diperkenalkan kembali. Negara secara besar-besaran mendukung program belajar bahasa yang dimulai dengan program belajar bahasa Latvia pada penduduk Rusia yang pada masa lalu menggunakan bahasa Rusia sebagai bahasa satu-satunya yang mereka kuasai. Demikian juga dengan bangkitnya generasi teknologi cina yang disponsori dengan bahasa Mongolianya, bahasa jepang dan Korea yang masuk dalam rumpun bahasa Altiac, Perancis, Portugis, Italia, dan Spanyol yang masuk dalam rumpun Indoeropa, semua itu menujukkan betapa suksesnya Negara ini karena bahasa nasional mereka yang menjadi pondamental.

Pertanyaan yang perlu kita jawab adalah, mengapa bahasa Indonesia dipersoalkan sedemikian rupa? Untuk menjawab pertanyaan ini mari kita lihat dari beberapa sudat pandang yang berbeda..Pertama, ada peran psikologis di mana bahasa bermain, dalam hal ini mengikat dalam penghargaan diri dan kebanggaan kelompok serta mdividu.Kedua, bahasa sering dilihat sebagai milik utama yang mempunyai signifikansi kultural dan juga nilai praktis dalam kehidupan. Itu sebabnya, ketika suatu komunitas harus menggunakan bahasa lain, bukan bahasa aslinya dalam berinteraksi dengan komunitas lain dalam satu tatanan kehidupan yang lebih luas atau multikultural, maka akan memengaruhi derajat suka atau keterasingannya dari kehidupan tersebut dan ketiga, karena bahasa Indonesia hampir tidak lagi menjadi milik bangsa Indonesia.

Dengan mengamati peristiwa di atas serta dampak psikologis dan sosiologis dari peran bahasa lalu bagaimana dengan bangsa Indonesia, yang di samping terdapat bahasa Indonesia yang berkedudukan sebagai bahasa nasional dan bahasa resmi kenegaraan juga tumbuh beratus-ratus bahasa daerahP.Selain itu, juga tumbuh dan berkembang berbagai bahasa asing (Halim, 1982). Bagaimana pemerintah Indonesia termasuk di Sulawesi Tenggara membijaksanai kondisi kebahasaan yang pluralis. Akankah salah satunya harus dikorbankan?

Pandangan awal menganggap bahwa bahasa memang sesuatu yang diangap perlu namun disisi lain bahasa tidak diperlukan oleh pandangan 
kapitalis. Kapitalis berpandangan bahwa bahasa tidak memberikan kontribusi pada peningkatan ekonomi.Bahkan ada anggapan bahwa linguistik dianggap'sebagai kajian extravaganza saja.

Pada hal, sesungguhnya linguistik, khususnya linguistik fungsional sistemik, memberikan kontribusi yang banyak di dalam pembangunan ekonomi, sosial, budaya, dan politik yang selama ini tampaknya dilupakan dalam proses pembelajaran Bahasa Indonesia Khususnya, artinya perlu pemahaman komprehensif tentang stategi.

Untuk mendapatkan pemahaman yang komprehensif tentang strategi pembelajaran Bahasa Indonesia dan efektivitasnya terhadap pencapaian tujuan belajar, kajian ini akan difokuskan pada (1) pembelajaran bahasa, (2) strategi pembelajaran Bahasa Indonesia, meliputi metode dan teknik pembelajaran Bahasa Indonesia, dan (3) hasil pembelajaran. Pertama pembelajaran merupakan upaya membelajarkan siswa Degeng (1989). Kegiatan pengupayaan ini akan mengakibatkan siswa dapat mempelajari sesuatu dengan cara efektif dan efisien. Upaya-upaya yang dilakukan dapat berupa analisis tujuan dan karakteristik studi dan siswa, analisis sumber belajar, menetapkan strategi pengorganisasian, isi pembelajaran, menetapkan strategi penyampaian pembelajaran, menetapkan strategi pengelolaan pembelajaran, dan menetapkan prosedur pengukuran hasil pembelajaran. Oleh karena itu, setiap pengajar harus memiliki keterampilan dalam memilih strategi pembelajaran untuk setiap jenis kegiatan pembelajaran.Dengan demikian, dengan memilih strategi pembelajaran yang tepat dalam setiap jenis kegiatan pembelajaran, diharapkan pencapaian tujuan belajar dapat terpenuhi. Gilstrap dan Martin (1975) juga menyatakan bahwa peran pengajar lebih erat kaitannya dengan keberhasilan pebelajar, terutama berkenaan dengan kemampuan pengajar dalam menetapkan strategi pembelajaran.

Belajar bahasa pada hakikatnya adalah belajar komunikasi.Oleh karena itu, pembelajaran bahasa diarahkan untuk meningkatkan kemampuan pebelajar dalam berkomunikasi, baik lisan maupun tulis. Hal ini relevan dengan kurikulum 2013 bahwa is career of knowledge sehinggakompetensi pebelajar bahasa diarahkan ke dalam empat subaspek, yaitu membaca, berbicara, menyimak, dan mendengarkan.

Sedangkan tujuan pembelajaran bahasa, menurut Basiran (1999) adalah keterampilan komunikasi dalam berbagai konteks komunikasi. Kemampuan yang dikembangkan adalah daya tangkap makna, peran, daya tafsir, menilai, dan mengekspresikan diri dengan berbahasa. Kesemuanya itu dikelompokkan menjadi kebahasaan, pemahaman, dan penggunaan. Sementara itu, tujuan pembelajaran Bahasa dan Sastra Indonesia secara umum sebaiknya meliputi (1) siswa menghargai dan membanggakan Bahasa Indonesia sebagai bahasa persatuan (nasional) dan bahasa negara, (2) siswa memahami Bahasa Indonesia dari segi bentuk, makna, dan fungsi,serta menggunakannya dengan tepat dan kreatif untuk bermacam-macam tujuan, keperluan, dan keadaan, (3) siswa memiliki kemampuan menggunakan Bahasa Indonesia untuk meningkatkan kemampuan intelektual, kematangan emosional, dan kematangan sosial, (4) siswa memiliki disiplin dalam berpikir dan berbahasa (berbicara dan menulis), (5) siswa mampu menikmati dan memanfaatkan karya sastra untuk mengembangkan kepribadian, memperluas wawasan kehidupan, serta meningkatkan pengetahuan dan kemampuan berbahasa, dan (6) siswa menghargai dan membanggakan sastra Indonesia sebagai khazanah budaya dan intelektual manusia Indonesia. 
Untuk mencapai tujuan di atas, dalam proses pembelajaran bahasa harus mengaplikasikan prinsip-prinsip belajar Bahasa, serta menjadikan aspek-aspek tersebut sebagai petunjuk dalam kegiatan pembelajarannya. Prinsip-prinsip belajar bahasa dapat disarikan sebagai berikut: Pebelajar akan belajar bahasa dengan baik bila (1) diperlakukan sebagai individu yang memiliki kebutuhan dan minat, (2) diberi kesempatan berapstisipasi dalam penggunaan bahasa secara komunikatif dalam berbagai macam aktivitas, (3) bila ia secara sengaja memfokuskan pembelajarannya kepada bentuk, keterampilan, dan strategi untuk mendukung proses pemerolehan bahasa, (4) ia disebarkan dalam data sosiokultural dan pengalaman langsung dengan budaya menjadi bagian dari bahasa sasaran, (5) jika menyadari akan peran dan hakikat bahasa dan budaya, (6) jika diberi umpan balik yang tepat menyangkut kemajuan mereka, dan (7) jika diberi kesempatan untuk mengatur pembelajaran mereka sendiri (Aminuddin, 1994). Kedua, Strategi Pembelajaran Bahasa Indonesia tidak terlepas dari pembicaraan mengenai, metode, dan teknik mengajar dan pendekatan. Machfudz (2002) mengutip penjelasan Edward M. Anthony (dalam H. Allen and Robert, 1972) antara lain (a) Metode Pembelajaran berarti perencanaan secara menyeluruh untuk menyajikan mated pelajaran bahasa secara teratur. Istilah ini bersifat prosedural dalam arti penerapan suatu metode dalam pembelajaran bahasa dikerjakan dengan melalui langkahlangkah yang teratur dan secara bertahap, dimulai dari penyusunan perencanaan pengajaran, penyajian pengajaran, proses belajar mengajar, dan penilaian hasil belajar, (b) Teknik Pembelajaran mengacu pada pengertian implementasi perencanaan pengajaran di depan kelas, yaitu penyajian pelajaran dalam kelas tertentu dalam jam dan mated tertentu pula. Teknik mengajar berupa berbagai macam cara, kegiatan, dan kiat (trik) untuk menyajikan pelajaran dalam rangka mencapai tujuan pembelajaran.Teknik pembelajaran bersifat implementasi, individual, dan situasional.

Saksomo (1983) menyebutkan teknik dalam pembelajaran Bahasa Indonesia antara lain (1) ceramah, (2) Tanya-jawab, (3) diskusi, (4) pemeberian tugas dan resitasi, (5) demonstrasi dan eksperimen, (6) meramu pendapat (brainstorming), (7) mengajar di laboratorium, (8) induktif, inkuiri, dan diskoveri, (9) peragaan, dramatisasi, dan ostensif, (10) simulasi, main peran, dan sosiodrama, (11) karya wisata dan bermain-main, dan (12) eklektik, campuran, dan (c) Pendekatan Pembelajaran mengacu pada teori-teori bahasa dan pembelajaran Bahasa. Teori tentang hakikat bahasa mengemukakan asumsi-asumsi tentang hakikat bahasa, karakteristik bahasa, unsur-unsur bahasa, serta fungsi dan pemakaiannya sebagai media komunikasi dalam masyarakat bahasa. Teori belajar bahasa mengemukakan proses psikologis dalam belajar bahasa sebagaimana dikemukakan dalam psikolinguistik. Pendekatan pembelajaran lebih bersifat aksiomatis. Dari pendekatan ini diturunkan metode pembelajaran bahasa. Misalnya dari pendekatan berdasarkan teori ilmu bahasa struktural yang mengemukakan tesis-tesis linguistik menurut pandangan kaum strukturalis dan pendekatan teori belajar bahasa menganut aliran behavioerisme.

Pendekatan bersifat aksioma yang secara umum dapat menjadi pertimbangan untuk menguatkan kompetensi pebelajara bahasa.

Pendekatan yang saya maksudkan adalah pendekatan teritis antara lain:

\section{Pendekatan Linguistik}

Linguistik adalah kajian ilmiah tentang bahasa.Sesuatu kajian didasarkan pada satu pendekatan (approach). Pendekatan terhadap kajian bahasa didasarkan atas nilai dan anggapan dasar. 
Berbagai mahzab dan pendekatan dalam kajian bahasa telah menghasilkan banyak teori tentang bahasa, seperti tata bahasa tradisional, tata bahasa preskriptif, tata bahasa deskriptif, tata bahasa transformasi generatif, tagmemik, tata bahasa stratifikasional, tata bahasa relasional, tata bahasa kata, kesemestaan dan tipelogi bahasa, tata bahasa fungsional, tata bahasa leksikofungsional, dan lain-lain. Dalam perkembangan dan kejayaannya pelopor atau pengikut suatu pendekatan atau mahzab mengakui dan mendakwakan keunggulan pendekatan linguisti tertentu dibanding dengan teori linguistik lain. Sesungguhnya, masing-masing teori bahasa ini memiliki keunggulan dan kelemahan atau keterbatasan. Tidak satu pun teori bahasa yang terbaik atau terlengkap dan dapat digunakan untuk menyelesaikan segala masalah kebahasaan. Dalam sejarah perkembangannya, timbulnya satu pendekatan atau teori linguistik merupakan reaksi atau kritik terhadap kelemahan pendekatan yang mendahuluinya. Dengan kata lain, terjadi perubahan paradigma sepanjang zaman dalam (Saragih)

Berbagai ragam pendekatan linguistik atau teori kebahasaan, pada prinsipnya, dapat dikelompokkan ke dalam dua kubu, yaitu (1) kubu logical-philosophical dan (2) kubu ethnographicdescriptive (Halliday 1984: 4-8). Pandangan atau teori dalam satu kubu merupakan perbedaan atau pertentangan dari pandangan atau teori di kubu yang lain. Berbagai perbedaan pandangan terhadap kajian bahasa oleh kedua kubu itu menurut Martin (1992: 3) dan Kress (1990) dalam Saragih diringkas dalam tabel berikut.

\section{Perbedaan Pendekatan Logical-Philosophical dan Ethnographic-Descriptive}

\begin{tabular}{|l|l|l|}
\hline \multicolumn{1}{|c|}{ Aspek } & \multicolumn{1}{|c|}{ Logical-Philosophical } & \multicolumn{1}{c|}{ Ethnographic-Descriptive } \\
\hline pendekatan & $\begin{array}{l}\text { dari bentuk ke arti (form-meaning) } \\
\text { formal }\end{array}$ & $\begin{array}{l}\text { dari ard ke bentuk (meaning-form), } \\
\text { fungsional }\end{array}$ \\
\hline Anggapan & bahasa sebagai kaidah (rules) & bahasa sebagai sumber daya (resources) \\
\hline Kajian bahasa & lebih dekat ke logic & $\begin{array}{l}\text { lebih dekat ke sosial budaya, } \\
\text { antropologi }\end{array}$ \\
\hline $\begin{array}{l}\text { Bahasa erat } \\
\text { terkait }\end{array}$ & $\begin{array}{l}\text { dengan pikiran (neurology, } \\
\text { psychology) }\end{array}$ & $\begin{array}{l}\text { dengan gejala dan konteks sosial } \\
\text { (sociology, social contexts) }\end{array}$ \\
\hline Metode & $\begin{array}{l}\text { science, hampir ddak mengkaji } \\
\text { konteks sosial (pemakaian) bahasa }\end{array}$ & $\begin{array}{l}\text { semich menekankan kn } \text { sonteks } \\
\text { Bemakaian) bahasa }\end{array}$ \\
\hline Beberapa pelopor & $\begin{array}{l}\text { Modistae, Bloomfield, Chomsky, } \\
\text { Pike... }\end{array}$ & Hjelmslev, Matesius, Firth, HaUiday ... \\
\hline $\begin{array}{l}\text { umumnya } \\
\text { unggulan }\end{array}$ & di Amerika & di Eropah \\
\hline
\end{tabular}

\section{PENDEKATAN FORMAL}

Pendekatan formal, yang juga dikenal sebagai pendekatan bentuk-ard, mengkaji bentuk bahasa lebih dahulu, kemudian mencari ard bentuk bahasa itu. Pendekatan ini digunakan olehn ilmjuan dalam bidang ilmu- ilmu alam dan eksakta, kemudian diadopsi oleh ilmuan dalam bidang ilmu-ilmu sosial dan humaniora termasuk dalam penelidan bahasa. Dalam ilmu pengetahuan alam, misalnya, para ilmuwan (pada saat itu) mengatakan bahwa unsur terkecil dari suatu benda, entitas, atau maujud adalah atom.Atom 
bergabung dengan atom untuk membentuk molekul dan molekul bergabung dengan molekul membentuk sel dan selanjutnya sel bergabung dengan sel untuk membentuk benda atau makhluk hidup.Para pakar bahasa dalam pendekatan formal ini menganalogikan metode science dalam ilmu pengetahuan alam tersebut ke dalam kajian bahasa.Dengan analogi analisis itu, unsur yang terkecil dalam bahasa adalah bunyi, khususnya di dalam bahasa lisan. Unsur terkecil ini bergabung dengan bunyi lain untuk membentuk kata, kata bergabung dengan kata membentuf frase, yang selanjutnya bergabung membentuk kalimat yang mempunyai ard. Secara teknis unsur kajian bahasa, sejalan dengan bidang atau aspek kajian adalah fonologi, morfologi, sintaksis, dan semantik. Fonologi, morfologi, dan sintak dikatakan sebagai inti (core) kajian bahasa, sementara kajian semantik adalah unsur pendukung (peripheral). Dengan kata lain, kajian arti bukan merupakan unsur utama. Dengan dasar melihat bentuk form), konstruksi linguistik buku saya, istri soya, danhidung soya dipandang sebagai satu konstruksi saja karena semua bentuk itu berdasarkan rampatan (generated) atau dirampatkan sebagai kaidah Nomina + Peubah (Modifier). Demikian juga klausa Ali membeli mobil, AH menyukai mangga, AH merokok cerutu, Ali memerankan raja, daxAli menceritakan kejadian itu dikatakan terstruktur sama, yakni terdiri atas Subjek + Predikat + Objek.

\section{Pendekatan Fungsional}

Berbeda dengan pendekatan pertama, pendekatan fungsional, yang dikenal sebagai pendekatan arti-bentuk, bermula dari kajian arti ke bentuk. Prinsip fungsional adalah satu aspek bahasa (misalnya kata) dikaji berdasarkan fungsi yang dilakukan atau dimainkan kata itu dalam atau sebagai konstituen unsur yang lebih besar, misalnya frase atau klausa. Selanjutnya klausa dikaji sebagai unsur dalam unit linguistik yang lebih besar, misalnya wacana atau konteks sosial. Pendekatan fungsional bervariasi dalam pendekatan. Makalah ini difokuskan pada satu pendekatan fungsional, yaitu pendekatan linguistik fungsional sistemik (LFS).

Dalam perspektif LFS bahasa adalah sistem arti dan sistem lain (yakni sistem bentuk dan ekspresi) untuk merealisasikan arti tersebut. Kajian ini berdasar dua pandangan yang mendasar yang membedakan LFS dari aliran linguistik (fungsional) lain, yaitu (a) bahasa merupakan fenomena sosial yang wujud sebagai semiotik sosial dan (b) bahasa merupakan teks.

\section{Semiotik Sosial}

Bahasa dan pemakaian bahasa merupakan sistem semiotik. Sebagai semiotik, bahasa terjadi dari dua unsur, yakni arti dan ekspresi. Hubungan kedua unsur ini adalah hubungan realisasi, yakni arti direalisasikan atau dikodekan oleh oleh ekspresi. Namun, berbeda dengan semiotik biasa atau semiotik umum, sebagai semiotik sosial, bahasa memiliki unsur lain, yaitu bentuk. Dengan demikian, bahasa yang digunakan dalam interaksi sosial terdiri atas tiga unsur, yaitu arti, bentuk, dan ekspresi. Dengan tiga unsur ini bahasa dikatakan terdiri atas tiga strata, yaitu semantik atau arti, tata bahasa (lexicogrammary ${ }^{\wedge}$ g terdiri atas lexis fan. grammar), dan fonologi (dalam bahasa lisan), grafologi(dalam bahasa tulisan), atau isyarat [signs:gestures, facial expressions) sebagai ekspresi. Hubungan ketiga unsur ini dapat dikatakan sebagai: arti (semantik) direalisasikan bentuk (tata bahasa atau lexicogrammar), dan selanjutnya realisasi arti di dalam bentuk itu dikodekan oleh ekspresi (fonologi/grafologi/ isyarat). Sifat hubungan arti dan bentuk adalah alamiah (natural) dengan pengertian hubungan itu dapat dirujuk 
atau dijelaskan berdasarfkan konteks sosial, sementara hubungan antara arti dan ekspresi adalah arbitrar.

Bahasa (yang terdiri atas tiga strata: arti, tata bahasa, dan ekspresi) dan konteks sosial membentuk semiotik yang disebut semiotik pemakaian bahasa. Semiotik pemakaian bahasa menunjukkan hubungan bahasa (yang terjadi dari tiga strata) dan konteks sosial. Dengan demikian, dalam semiotik pemakaian bahasa ini berlangsung dua jenis semiotik, yaitu semiotik di tingkat bahasa, yang merupakan semiotik denotatif dan semiotik di tingkat konteks sosial, yang merupakan semiotik konotatif.

Sistem semiotik denotatif memiliki arti dan bentuk. Dalam pemakaian bahasa, semiotik denotatif terbentuk dalam hubungan antarstrata (level) dalam bahasa. Seperti dinyatakan terdahulu, semiotik denotatif bahasa menunjukkan bahwa arti direalisasikan oleh bentuk, yang selanjutnya direalisasikan oleh ekspresi (fonologi/ grafologi/isyarat). Dengan kata lain, semiotik denotatif bahasa menunjukkan bahwa semantik direalisasikan tata bahasa dan selanjutnya tata bahasa direalisasikan oleh fonologi (dalam bahasa lisan), grafologi (dalam bahasa tulisan), atau isyarat.

Semiotik konotatif berlangsung dalam konteks sosial, yang terdiri atas konteks situasi (register), konteks budaya (genre), dan ideologi. Berbeda dengan semiotik denotatif (yang memiliki arti dan bentuk), semiotik konotatif hanya memiliki arti dan tidak memiliki bentuk. Dalam keadaan demikian semiotik konotatif meminjam bentuk dari semiotik lain, yang lazimnya berada di bawahnya. Sebagai semiotik konotatif, konteks sosial membentuk strata dengan ideologi menempati strata tertinggi (dan dengan demikian disebut paling abstrak) yang diikuti oleh budaya dan konteks situasi. Semiotik konotatif pemakaian bahasa menunj ukkan bahwa ideologi tidak memiliki bentuk dan karena itu, semiotikini meminjam budaya sebagai bentuknya. Dengan cara ini, ideologi direalisasikan oleh budaya, yang juga tidak memiliki bentuk. Oleh karena tidak memiliki bentuk sendiri, budaya direalisasikan oleh konteks situasi. Selanjutnya, konteks situasi meminjam semiotik yang berada di bawahnya, yaitu bahasa, karena semiotik ini juga tidak memiliki bentuk. Dengan kata lain, konteks situasi direalisasikan oleh bahasa.

\section{Pendekatan Fokus pada Teks}

Teks dibatasi sebagai unit bahasa yang fungsional dalam konteks sosial (Halliday 2004). Bahasa yang fungsional memberi arti kepada pemakai bahasa. Dengan demikian, teks adalah unit arti atau unit semantik bukan unit tata bahasa (grammaticalunit), seperti klausa, frase, kata, dan morfem. Sebagai unit arti, teks dapat direalisasikan oleh berbagai unit bahasa atau unit tata bahasa. Hal ini berarti bahwa teks dapat berupa satu naskah (buku), paragraf, klausa kompleks, klausa, frase, grup, kata, morfem, atau bunyi. Yang menjadi kajian dalam LFS adalah arti. Oleh karena itu, yang menjadi pertanyaan adalah "Apakah satu unit bahasa itu berarti dalam konteks sosial?" Jika satu unit bahasa mempunyai arti dalam konteks sosial, unit bahasa itu disebut teks.

Hubungan bahasa atau teks dengan konteks sosial adalah hubungan konstrual; artinya konteks sosial menentukan dan ditentukan oleh teks. Dengan pengertian konstrual ini, pada satu waktu konteks sosial menentukan teks dan pada waktu berikutnya teks menentukan konteks sosial. LFS tidak menentukan yang mana lebih dulu terjadi: konteks atau teks. LFS hanya mengkaji hubungan antara keduanya sebagai saling menentukan (construal). Dalam satu konteks sosial tertentu hanya teks tertentu yang dapat dihasilkan. Sebaliknya, dengan teks tertentu 
hanya konteks sosial tertentu pula yang (dapat) dirujuk.

\section{KONTEKS KEBAHASAAN DI INDO- NESIA}

Pembelajaran bahasa Indonesia di sekolah dasar dan menengah diarahkan sebagai sarana pembinaan dan kesatuan bangsa, peningkatan pengetahuan dan keterampilan berbahasa Indonesia siswa, sarana penyebarluasan pemakaian bahasa Indonesia untuk berbagai keperluan, dan sarana pengembangan penalaran. Tujuan 'idealis' itu selanjutnya diturunkan ke dalam tujuan umum: (1) siswa menghargai dan membanggakan bahasa Indonesia sebagai bahasa persatuan (nasional) dan bahasa negara; (2) siswa memahami bahasa Indonesia dari segi bentuk, makna, dan fungsi, serta menggunakannya dengan tepat untuk bermacam-macam tujuan, keperluan, dan keadaan; (3) siswa menggunakan bahasa Indonesia untuk meningkatkan kemampuan intelektual (berpikir kreatif, menggunakan akal sehat, menerapkan pengetahuan yang berguna, dan memecahkan masalah), kematangan emosional dan sosial; dan (4) siswa mampu menikmati, memahami, dan memperluas wawasan kehidupan, serta meningkatkan pengetahuan dan kemampuan berbahasa. Demikian juga pembelajaran sastra, secara umum akan menjadi sarana pendidikan moral. Kesadaran moral dikembangkan dengan memanfaatkan berbagai sumber. Selain berdialog dengan orang-orang yang sudah teruji kebijaksanaannya, sumber-sumber tertulis seperti biografi, etika, dan karya sastra dapat menjadi bahan pemikiran dan perenungan tentang moral. Karya sastra yang bernilai tinggi di dalammnya terkandung pesan-pesan moral yang tinggi. Karya ini merekam semangat zaman pada suatu tempat dan waktu tertentu yang disajikan dengan gagasan yang berisi renungan falsafi. Sastra seperti ini dapat menjadi medium untuk menggerakkan dan mengangkat manusia pada harkat yang lebih tinggi. Karya sastra tersebut dapat berupa prosa fiksi, puisi, maupun drama.

Ke depan, pembelajaran sastra dikembangkan untuk mencapai tujuan-tujuan ideal seperti itu. Melalui pembelajaran sastra, anak diharapkan menjadi warga yang menjunjung tinggi nilai-nilai moral yang luhur.

Lalu, dalam konteks kecenderungan pemikiran seperd itu, bagaimanakah seharusnya pembelajaran bahasa Indonesia dikemas? Pendekatan pembelajaran yang bagaimanakah yang tepat untuk diterapkan?

Mengikuti pandangan di atas, pengajaran bahasa Indonesia seharusnya dikembalikan pada kedudukan yang sebenarnya, yaitu melatih siswa membaca, menulis, berbicara, mendengarkan, dan mengapresiasi sastra yang sesungguhnya. Tugas guru adalah melatih siswa membaca sebanyak-banyaknya, menulis sebanyak-banyaknya, berdiskusi sebanyakbanyaknya. Artinya, guru harus menghindari pengajaran yang berisi pengetahuan tentang bahasa Indonesia \{using the language, bukan talk about the language). Apa yang diajarkan seharusnya dekat dengan kebutuhan berbahasa Indonedia siswa.

Pengajaran bahasa Indonesia dijalankan melalui pendekatan komunikatif, pendekatan tematis, dan pendekatan terpadu. Pendekatan komunikatif mengisyaratkan agar pembelajaran bahasa Indonesia di sekolah dasar dan menengah diorientasikan pada penguasaan bahasa Indonesia sebagai alat komunikasi (bukan pembekalan pengetahuan kebahasaan saja). Pendekatan tematis menyarankan agar pembelajaran bahasa diikat oleh tema-tema yang dekat dengan kehidupan siswa, yang digunakan sebagai sarana berlatih membaca, mendengarkan, menulis, dan berbicara. Pendekatan terpadu menyarankan agar pengajaran bahasa Indonesia didasarkan pada wawasan Whole Language, yaitu 
wawasan belajar bahasa yang intinya menyarankan agar kegiatan pembelajaran bahasa Indonesia dilaksanakan terpadu antara membaca, mendengarkan, menulis, dan berbicara. Dengan konsep itu, dalam jangka panjang, target penguasaan kemahirwacanaan itu bisa tercapai.

Prinsip yang mendasari guru mengajarkan bahasa Indonesia sebagai sebuah keterampilan, antara lain pengintegrasian antara bentuk dan makna, penekanan pada kemampuan berbahasa praktis, dan interaksi yang produktif antara guru dengan siswa. Prinsip pertama menyarankan agar pengetahuan dan keterampilan berbahasa yang diperoleh, berguna dalam komunikasi sehari-hari (meaningful). Dengan kata lain, agar dihindari penyajian materi (khususnya kebahasaan) yang tidak bermanfaat dalam komunikasi sehari-hari, misalnya, pengetahuan tata bahasa bahasa Indonesia yang sangat linguistis. Prinsip kedua menekankan bahwa melalui pengajaran bahasa Indonesia, siswa diharapkan mampu menangkap ide yang diungkapkan dalam bahasa Indonesia, baik lisan maupun tulis, serta mampu mengungkapkan gagasan dalam bahasa Indonesia, baik secara lisan maupun tertulis. Penilaian hanya sebagai sarana pembelajaran bahasa, bukan sebagai tujuan. Sedangkan prinsip ketiga mengharapkan agar di kelas bahasa tercipta masyarakat pemakai bahasa Indonesia yang produktif. Tidak ada peran guru yang dominan. Guru diharapkan sebagai 'pemicu' kegiatan berbahasa lisan dan tulis. Peran guru sebagai orang yang tahu atau pemberi informasi pengetahuan bahasa Indonesia agar dihindari.

Bahasa, di sekolah, sebagai alat untuk mengajar dan belajar. Melalui penggunaan bahasa, guru mengomunikasikan apa yang diajarkan dan siswa mengekspresikan apa yang mereka pelajari (DeStefano, 1984:155). Untuk berhasil di dalam kelas, siswa harus belajar membaca, menulis, dan menghitung. Kemudian, keberhasilan di sekolah juga ditentukan oleh oleh keterampilan akademik dan interaksional. Ketepatan informasi harus disalurkan dengan menggunakan bahasa yang tepat pula. Jadi belajar membaca dan menulis diperlukan untuk menyelesaikan sebagian besar tugas bagi siswa (DeStefano, 1984:156157). Pertumbuhan kognitif adalah sebuah fungsi literasi. Kemampuan menulis mendorong pertumbuhan kognitif dan sebaliknya kognisi tumbuh bersama kemampuan menulis.

Di dalam berkolaborasi dengan guru kedka merencanakan, mengerjakan, dan melaporkan pekerjaan misalnya, siswa secara simultan belajar berbahasa, belajar melalui bahasa, dan belajar tentang bahasa. Mereka belajar berbahasa dengan menggunakan bahasa melalui mendengar, membaca, berdiskusi, dan membuat suatu perencanaan (menulis). Mereka juga belajar melalui bahasa, yakni ketika mempelajari dunia perkebunan misalnya dari buku-buku atau bacaan. Peristiwa mengobservasi dan kemudian melaporkannya adalah contoh belajar melalui bahasa.

Dengan belajar melalui bahasa, isi pelajaran dan bahasa secara simultan dipelajari. Meringkas pengalaman juga contoh belajar melalui bahasa. Lebih lanjut, kegiatan merencanakan kebun misalnya, sekaligus mencakup tiga aspek belajar bahasa secara simultan tanpa pengajaran secara langsung (melalui mata pelajaran bahasa). Guru memberikan konteks sosial dan intelektual yang mendukung pembelajaran dan penggunaan bahasa. Dalam kaitan ini, sesungguhnya guru merencanakan peristiwa literasi [literacy event) yang membuat siswa akrab untuk berpartisipasi secara mandiri. Tegasnya, dalam berbagai kesempatan, formal atau informal, guru menciptakan situasi dan siswa diberi pengalaman belajar berbahasa. 
Mereka membangun pemahaman terhadap dunia mereka melalui menyimak dan membaca dan mempresentasikannya melalui berbicara dan menulis (Piatt, 1989).

Khusus mengenai kegiatan menulis, ia mempunyai posisi tersendiri dalam kaitannya dengan upaya membantu siswa mengembangkan kegiatan berpikir dan pendalaman bahan ajar. Berdasarkan penyelidikannya terhadap guru, pembelajaran dan kegiatan menulis, menurut Raimes (1987), bertujuan (1) memberikan penguatan [reinforcement), (2) memberikan pelatihan [training), (3) membimbing siswa melakukan peniruan atau imitasi (imitation, (4) melatih siswa berkomunikasi [communication), (5) membuat siswa lebih lancar dalam berbahasa [fluency), dan (6) menjadikan siswa lebih giat belajar (learning). Keenam tujuan pedagogis menulis itu secara berurutan dijelaskan berikut ini.

Pertama, menulis untuk memberi penguatan hasil belajar bahasa \{writing for reinforcement). Tujuan pedagogis yang pertama ini mengarah kepada penguatan pemahaman unsur dan kaidah bahasa oleh siswa melalui penggunaan bahasa secara tertulis, Kedua, menulis untuk memberi pelatihan penggunaan bahasa \{writing for training). Tujuan pemberian pelatihan melalui menulis ini tidak terbatas pada pelatihan penggunaan bahasa (retorika dan struktur gramatika) dengan berbagai variasinya, tetapi juga dalam mengemukakan gagasan, Ketiga, menulis untuk melakukan peniruan (imitasi) penggunaan retorik dan sintaktik \{writing for imitation). Tujuan pedagogis ketiga ini mengarah pada upaya untuk meng-akrabkan siswa dengan aspek retorik dan sintaktik dalam menulis. Gaya pengungkapan gagasan dari wacana yang dibaca juga dapat "ditiru" untuk belajar, Keempat, menulis untuk berlatih berkomunikasi \{writing for communication). Melalui menulis siswa akan belajar berkomunikasi secara tertulis dalam kegiatan yang nyata. Pengalaman ini diharapkan juga memberi sumbangan dalam pengembangan kemampuan berkomunikasi secara lisan, Kelima, menulis untuk meningkatan kelancaran (writing for fluency). Kelancaran yang dimaksud mencakup kelancaran dalam menggunakan unsur dan kaidah bahasa serta kelancaran dalam mengemukakan gagasan dan Terakhir, menulis untuk belajar [writing for learning). Tujuan pedagogis terakhir inilah yang sangat erat kaitannya dengan upaya pengembangan budaya belajar secara mandiri melalui membaca-berpikir-menulis. Menulis untuk belajar mempunyai makna yang sangat dalam untuk membuat siswa belajar secara benar dalam arti yang seluas-luasnya.

Kegiatan menulis ternyata mempunyai peranan penting bagi siswa dalam mengembangkan keterampilan berpikir dan mendalami bahan ajar. Oleh karena itu, sudah selayaknya apabila menulis menjadi aktivitas penting dalam setiap pembelajaran di sekolah. Itu berarti, perlu dikembangkan kegiatan menulis lintas kurikulum, mengingat: (1) menulis, selain membaca dan mendengar, bermanfaat untuk belajar, (2) menulis dapat membantu siswa mempelajari informasi baru dalam mata pelajaran yang sedang dipelajari, (3) menulis memfasilitasi strategi-strategi pemecahan masalah siswa untuk mengorganisasi informasi lama dan baru, (4) menulis dapat mengajarkan siswa konvensi pragmatik dan kesadaran akan mitra (tutur/tulis) dan mengembangkan proses penting agar mampu berkomunikasi secara berhasil, (5) menulis dapat mengajarkan siswa mengevaluasi kekritisannya terhadap informasi yang mereka pelajari, dan (6) menulis dapat mengajarkan kepada siswa bagaimana mereka menerima atau menganalisis pengalaman-pengalaman personal mereka sendiri (Beach, 1984:183- 
184). Alasan-alasan tersebut sejalan dengan upaya mengembangkan strategi heuristik pada siswa. Dengan demikian menulis merupakan kegiatan yang sangat penting untuk semua mata pelajaran mengingat melalui menulis siswa dapat belajar bagaimana belajar, yakni melalui bagaimana membuat generalisasi, definisi, dan menerapkan skematanya terhadap sesuatu yang sedang dipelajari. Menulis tidak hanya bergantung pada proses kognitif tetapi juga dapat memberi penguatan afektif terhadap proses membaca. Oleh karena itu, menulis sebagai alat belajar perlu mendapat perhatian serius di sekolah (Beach, 1984). Guru dapat memberdayakan siswa menjadi berhasil dan independen dalam belajar dengan dua cara, mendokumentasikan efektivitas pengajaran yang dilakukan guru untuk memperbaiki hasil belajar, dan (2) guru menjadi mitra (partner) siswa dalam belajar (Eanes, 1997:54). Dengan kata lain, siswa membaca dan menulis untuk tujuan mencari, belajar, dan menerapkan informasi (isi) pelajaran. Dalam waktu vang bersamaan siswa dapat mengembangkan keterampilan literasi, misalnya: mengembangkan strategi membaca efektif, kebiasaan belajar secara efisien, memanfaatkan kosakata secara maksimal, berpikir kritis, dan percaya diri dalam menulis. Sebagai hasilnya, melalui aktivitas literasi akan memberdayakan siswa untuk mengadakan eksplorasi, meneliti, dan menikmati isi pengetahuan menurut kebutuhan dan minat mereka sendiri sebagai pembelajar yang independen (Eanes, 1997:54).

Dengan demikian, menurut McKenna dan Robinson (1990), hal itu dapat memaksimalkan pemerolehan isi pelajaran. Meskipun isi pelajaran memungkinkan diajarkan secara berhasil melalui pengajaran lisan secara langsung, McKenna dan Robinson mengidentifikasi empat alasan penting mengapa aktivitas kemahirwacaaan perlu dikembangkan. Pertama, hasil dari aktivitas literasi sebagai komplemen bagi pengajaran lisan dan meluaskan perspektif siswa. Kedua, aktivitas literasi memberikan sebuah tindak lanjut alamiah terhadap pengajaran langsung mendorong guru untuk melayani kebutuhan dan minat individual siswa. Ketiga, metode-metode terkini mengenai pengajaran langsung mencakup fase praktik, dalam hal ini aktivitas literasi tampaknya sangat sesuai. Keempat, siswa akan mempunyai tantangan untuk mengembangkan literasi isi lebih luas dari pengetahuan yang diperoleh dari disiplin ilmu dengan keterbatasan ruang lingkup dan waktu pelajaran. Kelas-kelas mata pelajaran merupakan seting yang ideal untuk praktik pengembangan keterampilan literasi. Terakhir, aktivitas literasi memberikan fondasi penting bagi perkembangan literasi dan belajar sepanjang hayat (Eanes, 1997:55). Aktivitas literasi juga dapat menjadikan siswa sebagai pembaca yang efektif, penulis yang kompeten, pemikir yang kritis, dan pembelajar yang mandiri.

Guru yang memberi pengajaran dan memberi kesempatan kepada siswa untuk mengajukan pertanyaan sendiri mengenai isi teks akan meningkatkan pembelajaran karena guru mendorong keakrifan siswa dengan melatih menyusun kembali teks dan membangun makna. Siswa yang dapat menjawab pertanyaannya sendiri akan dapat mengecek pemahamannya mengenai teks yang telah dibacanya (Palinscar, 2001). Melalui serangkaian proses pembelajaran yang kaya tersebut, diharapkan siswa akan dapat mengembangkan keterampilan berpikir dan sekaligus mendalami bahan ajar berbagai mata pelajaran yang sedang diikuti. Kedua hal tersebut sangat penting bagi siswa untuk keberhasilan belajarnya di sekolah. Dengan demikian, kegiatan menulis sebagai bagian dari aktivitas inti literasi perlu terus dikembangkan 
di sekolah melalui pembelajaran setiap mata pelajaran.

Agar tujuan tercapai, disarankan agar tugas-tugas (task) dan latihan dalam pembelajaran bahasa Indonesia dijalankan secara bervariasi, berselang-seling, dan diperkaya, baik mated maupun kegiatannya. Harus disadari benar oleh guru bahwa kegiatan berbahasa itu tak terbatas sifatnya. Membaca artikel, buku, iklan, brosur; mendengarkan pidato, laporan, komentar, berita; menulis surat, laporan, karya sastra, telegram, mengisi blangko; berbicara dalam forum, mewawancarai, dan sebagainya adalah contoh betapa luasnya pemakaian bahasa Indonesia itu.

Gambaran tujuan dan prinsip-prinsip pengembangan pembelajaran bahasa Indonesia di atas sejauh ini masih jauh terapannya di kelas riil sekolah. Harapan bahwa dengan pembelajaran bahasa Indonesia anak-anak dapat membaca dengan baik, menulis dengan lancar, dan berbicara dengan sopan, baik, dan berani, masih 'jauh panggang dari api'. Sebagian besar, guru masih berkutat pada penyampaian teori yang tak relevan dengan kebutuhan berkomunikasi. Permasalahan yang dihadapi pengajaran bahasa Indonesia masih kompleks dan perlu pembinaan terus-menerus. Masukan-masukan yang berupa laporan yang berasal dari keadaan nyata di sekolah akan sangat berarti bagi penentu kebijakan.

Saat ini, bahasa Indonesia sudah menjadi bahasa pertama bagi sebagian besar siswa di Indonesia. Artinya, kedka masuk sekolah, siswa telah terpajani oleh lingkungan berbahasa Indonesia. Tugas guru adalah meningkatkan kemampuan itu melalui kegiatan berbahasa Indonesia nyata, bukan mengajarkanilmu tentang bahasa Indonesia. Hanya, yang terjadi kemudian adalah (1) guru lebih banyak menerangkan tentang bahasa (form-focus), (2) tata bahasa sebagai bahan yang diajarkan, (3) keterampilan berbahasa nyata kurang diperhatkan, (4) membaca dan menulis sebagai sesuatu yang diajarkan, bukan sebagai media berkomunikasi dan berekspresi.

Penekanan pembelajaran bahasa Indonesia hanya pada tata bahasa, yang relevansinya dengan kebutuhan berbahasa kurang. Murid hanya menghafal jenis kata, pengertian kalimat, fungsi-fungsi awalan, dan beragam peribahasa usang. Lalu pertanyaannya, manakah kemampuan membaca dan menulis kreatif yang seharusnya dikuasai siswa melalui pengajaran bahasa Indonesia?

Sebaiknya, pengajaran bahasa Indonesia dikembalikan pada kedudukan yang sebenarnya, yaitu melatih siswa membaca sebanyak-banyaknya, menulis sebanyakbanyaknya, berdiskusi sebanyak-banyaknya. Misalnya, membaca berita, membaca cerpen, membaca iklan, menulis surat, menulis iklan baris, membuat laporan, mendengarkan berita, membacakan pengumuman, dan sejenisnya. Dengan demikian, PBI akan menjadi pelajaran yang menarik dan 'berguna'. Jika tata bahasa harus diajarkan, sebenarnya hanya untuk menunjang kemampuankemampuan tersebut. Guru disarankan agar kembali berpegang pada sasaran tujuan pengajaran bahasa Indonesia, yaitu melatih siswa menggunakan bahasa Indonesia dalam situasi berbahasa nyata. Materi-materi yang tingkat kebergunaannya rendah, seperti teori tata bahasa umum dan pengetahuan tentang tata bahasa sebaiknya dikurangi.

\section{KONTEKS}

Konteks pemakaian bahasa dibatasi sebagai segala sesuatu yang berada di luar teks atau pemakaian bahasa. Kata konteks [context] dapat dirinci berasal dari kata co- yang berarti bersama atau mendampingi dan text, yakni setiap unit bahasa, karena pada prinsipnya setiap unit bahasa adalah teks. Dengan demikian, 
konteks mengacu kepada segala sesuatu yang mendampingi teks. Dengan pengertian ini, dalam perspektif LFS, konteks mencakup dua pengertian, yakni (1) konteks linguistik (yang disebut juga konteks internal) dan (2) konteks sosial (yang disebut juga konteks eksternal).

\section{Konteks Linguistik}

Konteks linguistik mengacu kepada unit linguistik lain yang mendampingi satu unit yang sedang dibicarakan. Dengan batasan pengertian ini, dalam klausa Saya akan pergi be Jakarta besok unit Soya akan...ke Jakarta besok merupakan konteks bagi unit pergi ketika seseorang membicarakan kata pergi itu. Unit linguistik lain yang mendampingi suatu unit linguistik yang sedang dibicarakan sering juga disebut konteks internal atau koteks (cotext). Dikatakan konteks internal karena konteks ini berada di dalam dan merupakan bagian dari teks yang dibicarakan.

\section{Konteks Sosial}

Berbeda dengan konteks atau konteks linguistik, konteks sosial mengacu kepada segala sesuatu di luar yang tertulis atau terucap, yang mendampingi bahasa atau teks dalam peristiwa pemakaian bahasa atau interaksi sosial. Konteks seperti ini disebut juga konteks eksternal. Seperti diuraikan terdahulu, konteks sosial ini terbagi ke dalam tiga kategori, yaitu konteks situasi, konteks budaya (disebut juga. genre), dan konteks ideologi (Martin, 1992, 1993). Ketiga konteks sosial ini membentuk strata dengan pengertian strata yang paling dekat ke bahasa lebih konkret daripada strata yang lebih jauh dari bahasa. Berdasarkan strata kedekatan kepada bahasa, konteks sosial secara berurut mulai dari konteks situasi, budaya, dan ideologi.

Konteks situasi terdiri atas apa (field) yang dibicarakan, siapa (tenor) yang membicarakan sesuatu bahasan, dan bagaimana (mode) pembicaraan itu dilakukan. Secara rinci, field menunjuk peran bahasa atau topik yang dibicarakan dalam interaksi sosial, tenor menggambarkan status (sama atau setara, tidak sama atau berbeda), suka atau tidak suka (affect), hubungan (biasa atau baru pertama kali) antarpemakai bahasa (addresser dan addressee), dan mode mengurai sarana, medium, atau saluran pemakaian bahasa yang dapat berupa lisan atau tulisan. Dalam interaksi bahasa, ketiga aspek konteks situasi itu dapat diidentifikasi. Namun, dalam beberapa situasi dapat terjadi satu aspek tidak jelas atau tidak teridentifikasi yang dalam keadaan demikian aspek situasi disebut netral.

Konteks budayamemengaruhipemakaian bahasa atauteks dalam hal budaya menentukan jenis teks yang digunakan pemakai bahasa. Dalam hal ini budaya dibatasi sebagai aktivitas sosial bertahap untuk mencapai suatu tujuan. Dengan pengertian ini, konteks budaya mencakup tiga hal, yaitu (1) batasan kemungkinan ketiga unsur konteks situasi, (2) tahap yang harus dilalui dalam satu interaksi sosial, dan (3) tujuan yang akan dicapai dalam interaksi sosial. Pada dasarnya, setiap interaksi sosial mempunyai tujuan tertentu. Tujuan ini sering juga disebut fungsi teks tersebut.

Ideologi mengacu kepada konstruksi atau konsep sosial yang menetapkan apa seharusnya dan tidak seharusnya dilakukan oleh seseorang dalam satu interaksi sosial. Dengan batasan ini, ideologi merupakan konsep atau gambar ideal yang diinginkan atau diidamkan oleh anggota masyarakat dalam satu komunitas, yang terdiri atas apa yang diinginkan atau yang tidak diinginkan terjadi. Ideologi bagi pemakai bahasa merupakan panduan dalam berbuat atau memroduksi teks dan menjadi saringan atau filter dalam bereaksi terhadap pengaruh dari luas suatu komunitas. Tidak ada pembuatan atau pemahaman teks yang bebas nilai atau 
ideologi. Dengan kata lain, ideologi berada secara nyata atau laten dalam setiap teks.

Mengajar bahasa berarti mengajarkan halhal yang berhubungan dengan bahasa seperti elemen bahasa dan komponen bahasa serta keterampilan berbahasa. Dalam penegajaran bahasa penekanan pada keterampilan bebrbahasa seperti keterampilan mendengarkan, menulis, berbiciara dan membaca sangat penting. Keempat keterampilan tersebut perlu didukung oleh kemampuan penguasaan komponen berbahasa. Dalam beberapa terbitan buku pengajaran bahasa, tampaknya mated pengajaran bahasa tidak menyentuh pada aspek elemen dan koponen serta keterampilan berbahasa.

Kondisi kebahasaan yang digambarkan di atas jelas akan memengaruhi upaya pembinaan dan pengembangan bahasa di Indonesia. Untuk itu, pemerintah melalui institusi yang diberi legitimasi untuk menangani masalah kebahasaan di SulawesiTenggara, dalam hal ini Kantor Bahasa, telah menggariskan arah kebijakan pembinaan bahasa (dan sastra) di Sulawesi Tenggara, Dalam kebijakan Politik Bahasa Sulawesi Tengara diarahkan untuk mendukung kebijakan bahasa nasional yang berisi pengarahan, perencanaan, dan ketentuan-ketentuan yang dapat dipakai sebagai dasar pengelolaan keseluruhan masalah kebahasaan (dan kesastraan) di Indonesia. Keseluruhan masalah itu merupakan jaringan masalah yang dijalin oleh (1) masalah bahasa dan sastra Indonesia, (2) masalah bahasa dan satra daerah, dan (3) masalah bahasa asing di Indonesia. Pengelolaan keseluruhan masalah tersebut diperlukan adanya suatu kebijakan nasional yang dirumuskan sedemikian rupa sehingga pengelolaan masalah kebahasaan itu benarbenar berencana, terarah, dan menyeluruh.
Berdasarkan rumusan fungsi ketiga jenis bahasa tersebut, maka dalam konteks keindonesiaan, pemakaian bahasa Indonesia merupakan prioritas utama, karena selain sebagai identitas nasional bahasa Indonesia mempersatukan berbagai etnis baik secara politis, sosial, maupun ekonomis; sedangkan bahasa daerah digunakan sebagai pengantar dalam hubungan intraetnis. Sebagai bahasa etnis, bahasa daerah mengalami marginalisasi karena peran bahasa nasional yang begitu intens. Sementara itu, keberadaan bahasa asing mendesak upaya maksimalisasi pemakaian bahasa Indonesia sehingga keberadaan bahasa Indonesia dan bahasa daerah sebagai aset nasional menjadi sangat mengkhawatir. Hal ini dapat dilihat dari misalnya, rendahnya mutu pemakaian bahasa Indonesia dan bahasa daerah. Padahal, keberadaan bahasa daerah di Indonesia merupakan salah satu penanda keberagaman bangsa Indonesia.Untuk itu, diperlukan upaya yang sungguh-sungguh dalam mengajarkan bahasa dan sastra Indonesia dan daerah.

\section{TANTANGAN DAN PELUANG TENAGA PENDIDIK KEBAHASAAN DI INDONESIA}

Tenaga pendidik kebahasaan yang dimaksud dalam seksi ini adalah tenaga pendidik bahasa Indonesia dan bahasa daerah. Oleh karena itu, pembicaraan ihwal tantangan dan peluang tenaga pendidik kebahasaan yang dimaksudkan adalah tantangan dan peluang bagi tenaga pendidik bahasa dan sastra Indonesia dan daerah.

\section{Relevansi kurikulum dan Metode dan teknik pembelajaran}

Metode dan teknik pembelajaran bahasa merupakan unsur yang sangat berpengaruh dalam pemerolehan bahasa.Tidak ada satu pun metode atau teknik yang lebih baik dari metode dan teknik yang lainnya, tergantung 
bagaimana seorang untuk memanfaatkan fungsi otak kiri dan otak kanan dalam menerima rangsangan bahasa dan memproduksi ujaran. Meskipun kegiatan pembelajaran bahasa telah berlangsung di dunia ini kurang lebih 25 abad lamanya (lihat Kelly, 1976), pembelajaran bahasa di Indonesia belum berusia satu abad. Pembelajaran bahasa di Indonesia, khususnya pembelajaran bahasa (dan sastra) Indonesia tidak lepas dari pengaruh pembelajaran bahasa yang berlangsung di dunia luar.Berbagai metode dan pendekatan pembelajaran bahasa yang berkembang di dunia luar diadopsi ke dalam pembelajaran bahasa Indonesia. Secara gads besar ada dua tekanan substansi pembelajaran bahasa di dunia yang ikut mewarnai mated pembelajaran bahasa di Indonesia, yaitu pembelajaran dengan fokus utamanya pada bentuk (form) bahasa dan pembelajaran dengan fokus utama pada fungsi (function) bahasa. Apabila pada pembelajaran dengan penekanan pada bentuk bahasa lebih difokuskan pada penguasaan struktur (tata bahasa), maka pada pembelajaran dengan penekanan pada fungsi bahasa lebih difokuskan pada penguasaan penggunaan bahasa (dalam Mahsun, 2010). Hymes (1971) menjelaskan bahwa terdapat kaidah-kaidah penggunaan bahasa yang tanpa itu kaidahkaidah tata bahasa tidak akan ada gunanya. Belajar bahasa lebih sekadar mempersoalkan kegramatikalan, karena yang lebih penting adalah kecocokan (appropriateness) penggunaan suatu tuturan pada konteks sosiokulturalnya.Fokus pembelajaran dengan penekanan pada mated bentuk bahasa telah berlangsung sepanjang periode 1880 sampai dengan periode 1970-an; sedangkan pembelajaran dengan penekanan pada fungsi bahasa telah berlangsung mulai 1980-an.

Dari sudut pandang metodologi pembelajaran, maka pembelajaran bahasa dengan penekanan pada bentuk telah menjadi bahan utama bagi pendekatan pembelajaran bahasa dengan metode Grammar Translation Method, Direct Method, Audiolingual Method, Cognitive learning Theory, dan Communikative Approach (Kaswanti Purwa, 1990). Hanya saja, perbedaan di antara keempat metode tersebut terletak pada prosedur penyajian materinya. Apabila pada pendekatan Grammar Tanslation Method dan Cognitive Learning Theory mendahulukan tata bahasanya diuraikan lalu diikuti struktur bahasanya (induktif), maka pada pendekatan Direct Method dan Audiolingual Method yang didahulukan adalah struktur bahasanya baru diikuti uraian tata bahasanya (deduktif). Adapun penekanan pada mated penguasaan penggunaan bahasa telah menjadi pusat perhatian pembelajaran bahasa dengan metode Communicative Approach atau sering disebut pula dengan metode Functional/Notional Approach.

Untuk pembelajaran bahasa Indonesia di sekolah-sekolah penyajian mated yang menekankan pada kemampuan penguasaan bentuk bahasa (tata bahasa) telah mewarnai kegiatan pembelajaran bahasa sepanjang era awal kemerdekaan sampai awal tahun 1984. Kondisi ini menyebabkan muncul buku-buku tata bahasa Indonesia yang telah menjadi buku pegangan utama pembelajaran bahasa Indonesia di sekolah-sekolah. Buku tata bahasa yang sangat kuat pengaruhnya dalam pembelajaran bahasa Indonesia adalah karangan Sutan Takdir Alisyahbana (1949). Buku ini sangat luas dan panjang masa beredarnya. Tahun 1981 jilid pertamanya telah mengalami cetak ulang sebanyak 43 kali dan tahun 1980 jilid keduanya mengalami cetak ulang sebanyak 30 kali. Disusul kemudian oleh buku tata bahasa karangan Gorys Keraf, yang diterbitkan 1970 dan mengalami cetak ulang sebanyak 10 kali tahun 1984.

Dengan munculnya Kurikulum 1984, pembelajaran bahasa Indonesia di Indonesia memasuki periode baru, yaitu 
pembelajarannya

tidaklagiditekankanpadapenguasaanpadabentu $\mathrm{k}$ bahasa tetapi pada fungsi bahasa. Kurikulum 1984 tidak hanya menjadikan pragmatik sebagai pendekatan dalam pembelajaran bahasa, tetapi pragmatik dijadikan materi pembelajaran bahasa itu sendiri. Dalam pembelajaran bahasa yang menjadikan pragmatik sebagai materi sekaligus pendekatan dalam pembelajaran bahasa pembelajar lebih dituntut untuk menguasai penggunaan bahasa bukan pada penguasaan kaidahdtaidah bahasa. Belajar bahasa bukan belajar tentang bahasa tetapi belajar berbahasa (belajar menggunakan bahasa). Dalam periode ini penekanan pada aspek SPO (subkjek, prodekat dan objek) tidak mengabaikan pada penggunaan fungsional.

Pola penataan materi dan metode pembelajaran bahasa Indonesia dengan berbasis pada tujuan pembelajaran bahasa sebagai upaya penguasaan bahasa secara baik dan benar terus diperkuat dan dipertegas dengan lahirnya kurikulum baru, yaitu Kuriklum Tingkat Satuan Pendidikan. Namun, sayangnya sebegitu rapinya struktur KTSP yang dikembangkan sekarang ini tidak juga membuat prestasi belajar bahasa Indonesia para pembelajar di pendidikan formal yang menggembirakan.

Adakah hal ini disebabkan oleh perasaan bahwa setiap warga negara Indonesia yang belajar bahasa di dunia pendidikan formal itu berangkat dengan modal "merasa sudah dapat berbahasa Indonesia" dengan baik, benar dan beretika? Dengan kata lain, tenaga pendidik Indonesia yang mengajar bahasa Indonesia pada siswa yang berbahasa Indonesia merupakan tantang terberat. Tantangan ini menjadi sangat krusial karena siswa yang diajar berbahasa Indonesia tersebut menempatkan bahasa pada fungsi sosialnya sebagai sarana komunikasi saja. Sebagai sarana komunikasi, penguasaan kaidah bahasa cukup seperlunya tidak perlu bersusah payah, toh sasaran akhir pemahaman bahasa itu adalah adanya kontak antara pihak yang terlibat dalam peristiwa berbahasa itu. Dengan kata lain, modal itu dikukuhkan oleh kenyataan bahwa ketika mereka berbicara dengan menggunakan bahasa Indonesia antar mereka satu sama lain masih dapat saling memahami. Memang perasaan "merasa sudah dapat..." tetang sesuatu menjadi kendala psikologis bagi seseorang untuk menguasai lebih dalam tentang sesuatu yang dia rasakan sudah dikuasai tersebut.

Selain itu, tantangan yang tidak kalah beratnya bagi pembelajaran BI pada penutur yang berbahasa Indonesia adalah, (a) demam pada sesuatu yang berlabel internasional yang ditandai oleh banyaknya bermunculan SBI yang indikatornya menggunakan bahasa pengantar bahasa asing, (b) sikap keterjajahan yang selalu menjadi subordinat negara asing termasuk masalah pemakaian bahasa, dan (c) kedua hal itu membawa konsekuensi pada munculnya sikap negatif pada bahasa Indonesia.

\section{Relevansi Materi dengan tujuan Pembela- jaran}

Demikian juga pengajaran bahasa Indonesia lebih menekankan pada aspek medianya dari pada aspek bahasanya. Dalam buku pelajaran bahasa Indonesia untuk SMA/MA kelas XII semester 1 tulisan Setyartiningsih, S.Pd., terbitan Pratama Mitra Aksara (tanpa tahun) pada standart kompetensi dicantumkan ada empat yang ingin dicapai antara lain (1) memahami informasi, (2) mengungkapkan pendapat, (3) memahami artikel dan pidato, dan (4) mengunkapkan infromasi dalam bentuk surat dinas. Sedangkan kompetensi dasarnya dalah (1) membedakan antara fakta, (2) menagapi pembacaan puisi, menemukan ide pokok dan 
permasalahan dalama artikel, dan (4) menulis surat lamaran. Dari standart kompetensi dan kompetensi dasar tersebut sama sekali ddak terakomodir dalam perumusan soal-soal yang membicarakan perihal bahasa. Demikian juga pada mata pelajaran bahasa Indonesia kelas 2 terbitan Yudistira tahun 2010, pelajaran pertama sampai terakhir saya tidak menemukan penggunaan huruf kapital, apakah memang sudah seperti itu?

Tantangan bagi tenaga pendidik bahasa Indonesia di atas sekaligus menjadi peluang yang sangat strategis bagi tenaga pendidik untuk menemukan materi atau metode pembelajaran bahasa pada penutur yang sudah "dapat" menggunakan bahasa tersebut. Dalam tataran ini, tenaga pendidik bahasa Indonesia dituntut untuk mencurahkan pikirannya untuk merumuskan dan memformulasikan materi pembelajaran bahasa Indonesia yang dapat memotivasi mereka untuk belajar sungguhsungguh serta menemukan cara-cara yang menarik untuk penyajian materi itu.

Apabila kita menelaah secara seksama materi pembelajaran bahasa Indonesia dari tingkat sekolah dasar sampai ke perguruan tinggi, tidak ada satu pun pokok bahasan yang mencoba memotivasi pembelajar agar mau belajar bahasa Indonesia dengan sungguhsungguh. Dengan kata lain, dalam materi pembelajaran bahasa Indonesia tersebut tidak ditemukan satu materi pembelajaran yang dapat memotivasi agar siswa mau menanggalkan perasaan "merasa sudah dapat berabahasa Indonesia" itu. Untuk itu, menur ut hemat saya ada satu materi pembelajaran bahasa Indonesia yang dilupakan untuk disajikan sebagai upaya menciptakan prakondisi sebelum belajar menggunakan bahasa Indonesia secara baik dan benar diberikan. Materi itu adalah materi "Sejarah Bahasa Indonesia", yang secara umum substansi isinya digambarkan berikut ini.
Untuk itu, materi pembelajaran bahasa Indonesia paling tidak memuat tentang fase antara lain sejarah BI hendaknya memperlihatkan peran BI dalam tiga fase historis terbentuknya nasionalitas, bangsa, dan negara Indonesia, seperti dikemukakan Anwar (2008) berikut ini, (1) fase pembentukan konsep kebangsaan, (b) fase pergerakan kemerdekaan, dan, (c) fase penanaman identitas.

\section{Tantangan Bahasa Asing dan Bahasa Daerah}

Seperti halnya tantangan dan peluang yang dihadapi tenaga pendidik bahasa dan sastra Indonesia, tantangan dan peluang yang dihadapi oleh pendidik bahasa daerah pun relatif sama, yaitu untuk tingkat permulaan pembelajaran bahasa daerah dilakukan pada siswa yang memiliki bahasa daerah tersebut. Sehingga di sini dituntut pendidik untuk dapat berkreasi meramu materi dan menetapkan metode yang cocok bagi pembelajaran bahasa daerah pada penuturnya sendiri. SeFain tantangan di atas, tenaga pendidik bahasa dan sastra daerah memilik tantangan lain seperti, (a) Otonomi daerah menuntut identitas kedaerahan, (b) Kehendak memunculkan mulok bahasa daerah, (c) Desakan agar menggunakan bahasa pengantar bahasa ibu dan (d) Kondisi ini (b dan c) bagai gayung bersambut dengan kondisi (a), sehingga dituntut guru yang mampu mendesain pembelajaran bahasa daerah yang tidak membentuk semangat etnosentris yang berlebihan.

Apabila kewenangan daerah yang dimaksudkan dalam Undang-undang Nomor 22 tahun 1999 dikaitkan dengan kebijakan politik bahasa nasional yang dirumuskan tahun 2000, sebagai jabaran dari penjelasan pasal 36 UUD 1945, maka dapatlah dikatakan bahwa kewenangan untuk memelihara dan mengembangkan bahasa-bahasa daerah 
sebagai bagian dari unsur kebudayaan Indonesia dilakukan oleh masing-masing daerah yang memiliki bahasa itu sendiri. Apresiasi terhadap konsep pemeliharaan dan pembinaan bahasa bahasa daerah oleh masing-masing daerah dapat muncul dalam bentuk yang beranekaragam. Hal ini lebihlebih jika dikaitkan dengan spirit yang terkandung dalam Undang-Undang Nomor 22 tahun 1999 itu adalah pemberian wewenang seluas-luasnya bagi daerah untuk berkembang dengan memanfaatkan potensi yang ada di daerah itu sendiri secara maksimal. Keadaan ini akan memunculkan kondisi saling menyaingi antardaerah dalam mengembangkan potensi yang ada di masingmasing wilayah (daerah). Persaingan itu, termasuk pula persaingan dalam upaya merealisasikan apresiasi mereka terhadap pemeliharaan dan pengembangan kebudayaan daerah, yang di dalamnya termasuk bahasa (daerah) seperti yang diamanatkan dalam UUD 1945 tersebut.

Seiring dengan itu, suasana yang semakin memberi ruang gerak bagi berkembangnya semangat kedaerahan akan semakin terbuka. Itu artinya, bahwa apabila kondisi yang memberi otonomi yang seluas-luasnya pada daerah untuk mengatur dirinya sendiri ddak difahami dalam konteks hidup berbangsa dan bernegara, maka dapat menjadi ancaman bagi kelangsungan hidup Negara Kesatuan Republik Indonesia. Kasus pengakuan penutur isolek Adonara Timur dan Adonara Barat yang mengklaim bahwa mereka menggunakan isolek yang bersatatus bahasa yang berbeda hanya karena keinginan Adonara Timur membentuk daerah otonom baru (kabupaten) yang terpisah dari Adonara Barat, atau kehendak masyarakat di Wilayah Kabupaten Sumbawa Barat membentuk Lembaga Adat sendiri yang terpisah dari Lembaga Adat Sumbawa setelah mereka berhasil membentuk daerah otonom baru merupakan bentuk ekstrim dari kondisi otonomi daerah yang justeru akan menggoyahkan persatuan bangsa. Kemungkinan akan terwujudnya kekhawadran ini semakin didukung oleh angin reformasi yang mulai terhembus dalam satu dasawarsa terakhir ini dan arus globalisasi yang cenderung menuntut sedap komunitas, baik dalam lingkup kedaerahan maupun nasional untuk memiliki jati did yang kuat demi memenangkan persaingan yang begitu ketat. Kiranya masih segar dalam ingatan kita, beberapa kasus yang mengarah pada disintegrasi nasional, seperti kasus Maluku dan Papua masih menjadi ancaman bagi keutuhan NKRI.

Namun, sebenarnya kekhawatiran dan kasus-kasus di atas tidak harus terjadi selama potensi keanekaragaman budaya yang tercermin pada daerah-daerah yang membentuk negara Kesatuan Republik Indonesia ini dapat dikelola secara baik. Pengelolan yang dimaksud salah satunya dalam bentuk memperkuat rasa kebersamaan dalam perbedaan melalui penumbuhan kesadaran secara suka rela berdasarkan pemahaman yang tidak bersifat memaksa, tetapi berdasarkan perenungan yang intens melalui justifikasi empirik yang memang dapat dicerna akal sehat (rasional) .Pengelolan yang demikian itu haruslah menjadi kebijakan nasional yang dimungkinkan untuk diterapkan di daerah-daerah. Untuk itu diperlukan titik tolak yang sama, yang menjadi komitmen bersama.

Dalam konteks itu, keberadaan bahasabahasa daerah di Indonesia, yang tidak kurang dari 471 buah (Identifikasi Pusat Bahasa, 2009), dapat membantu menyediakan bukti empirik guna memberi inspirasi bagi perenungan yang intens serta menjadi titik pijak yang sama untuk menumbuhkan komitmen bersama. Bukti yang dimaksud berupa data-data yang menunjukkan 
kekerabatan antarbahasa yang ada berupa kesepadanan kaidah-kaidah kebahasaan, baik kesepadanan pada tataran bunyi, maupun kesepadanan pada tataran gramatika (morfologi dan sintaksis), dan tataran makna (semantik). Dengan memanfaatkan kajian linguistik, khususnya linguistik historis komparatif dan dialektologi diakronis, bentuk-bentuk yang berkesepadanan (berkorespondensi) itu dapat dijelaskan sebagai bentuk yang berbeda tetapi berasal dari satu bentuk yang sama, yang diwujudkan melalui pengembangan materi muatan lokal bahasa daerah yang berdimensi kebhinnekaan untuk diajarkan di sekolah-sekolah (termasuk perguruan tinggi).

Untuk materi yang mengandung dimensi kebhinnekaan akan dititipkan pada pembahasan aspek kebahasaan, khususnya pada subtopik pembahasan kosakata. Materi tersusun berupa teks bacaan dalam dialek bahasa Standar yang di dalamnya sengaja dimasukkan unsur-unsur leksikal yang memiliki relasi kekerabatan dengan unsurunsur leksikal dialek-dialek atau bahasa-bahasa lainnya.

Pada pembahasan subtopik kosa kata, unsur leksikal dialek standar yang memiliki relasi kekerabatan tersebut diangkat kembali untuk ditunjukkan padanannya dalam dialekdialek lain dari bahasa yang diajarkan atau dengan bentuk berkerabat dalam bahasa lain sesuai dengan tujuan pembelajarannya. Pada saat itulah guru menjelaskan hakekat perbedaan dari unsur-unsur leksikal tersebut dengan mengaitkannya pada sebuah bentuk asal yang sama. Bersamaan dengan itu pula, pesan keanekaragaman dalam ketunggalikaan dapat disampaikan. Mengingat bahwa banyaknya bahasa daerah yang tumbuh dan berkembang di Indonesia maka sungguh amat banyak bentuk berkerabat yang akan ditemukan di antara bahasa-bahasa itu. Untuk itu, penataan materi disesuaikan dengan tingkat pendidikan siswa.Untuk tingkat sekolah dasar pembelajaran bentuk berkerabat dapat diprioritaskan pada bentuk berkerabat dalam bahasa yang diajarkan, jadi berupa bentuk berkerabat dalam dialek-dialek bahasa itu disamping mengajarakan bahasa untuk pengembangan logika, etika, dan estetika. Pada skala yang lebih luas model yang dikembangkan pada level daerah itu dapat ditingkatkan menjadi model yang dapat berlaku pada lintas daerah, misalnya setelah peserta didik mencapai jenjang pendidikan yang lebih tinggi, misal ketika mulai memasuki jenjang SLTP ke atas, dapat mengambil perbandingan pada lintas bahasa, bukan lagi lintas dialek dalam satu bahasa. Bahkan lebih jauh dari itu dapat dijadikan model untuk level nasional, dalam arti sistem pengajarannya yang bersifat kekerabatan-kontrastif tersebut dapat diambil pada bahan-bahan bahasa lain yang penuturnya lebih banyak dan memiliki tradisi tulis yang kuat, misalnya ketika mengajarkan materi muatan lokal bahasa Sasak di daerah yang berpenutur bahasa Sasak, bentuk yang berkerabat dapat dicarikan pada tingkat kekerabatan bahasa yang yang lebih tinggi misalnya, tingkat Autronesia seperti bahasa Sasak, Sumbawa, Melayu, Jawa, dan bahasa Tarpia di Papua, karena bahasa-bahasa itu merupakan bahasa-bahasa yang berkerabat pada level tersebut. Semakin tinggi tingkat pendidikan seseorangmaka semakin banyak bahasa daerah lain yang diketahui berkerabat dengan bahasa daerahnya, dan dalam pada itu akan semakin luaslah pemahamannya tentang makna yang terkandung dalam semboyan Bhinneka Tunggal Ika.

\section{HASIL}

Hasil pembelajaran adalah semua efek yang dapat dijadikan sebagai indikator tentang nilai dari penggunaan metode pembelajaran (Salamun, 2002).Variabel hasil pembelajaran dapat diklasifikasikan menjadi tiga bagian, 
yaitu kefektifav, (2) efisiensi, dan (3) daya tarik.

Hasil pembelajaran dapat berupa hasil nyata (actual outcomes), yaitu hasil nyata yang dicapai dari penggunaan suatu metode di bawah kondisi tertentu, dan hasil yang diinginkan (desired outcomes), yaitu tujuan yang ingin dicapai yang sering mempengaruhi keputusan perancang pembelajaran dalam melakukan pilihan metode sebaiknya digunakan klasifikasi variabel-variabel pembelajaran tersebut secara keseluruhan ditunjukkan dalam diagram berikut.

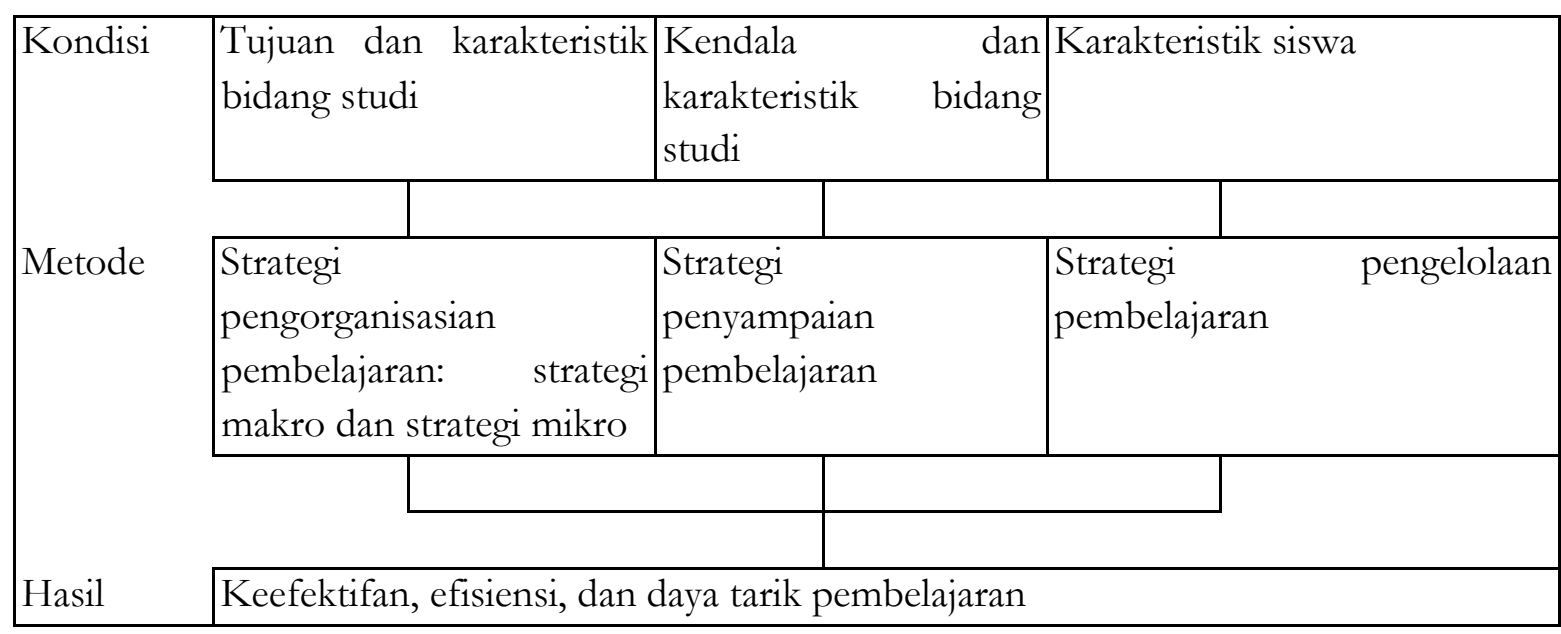

Diagram 1: Taksonomi variabel pembelajaran (diadaptasi dari Reigeluth dan Stein: 1983)

Keefektifan pembelajaran dapat diukur dengan tingkat pencapaian pebelajar. Efisiensi pembelajaran biasanya diukur rasio antara keefektifan dan jumlah waktu yang dipakai pebelajar dan atau jumlah biaya pembelajaran yang digunakan.Daya tatik pembelajaran biasanya juga dapat diukur dengan mengamati kecenderungan siswa untun tetap terus belajar. Adapaun daya tarik pembelajaran erat sekali dengan daya tarik bidang, studi.Keduanya dipengaruhi kualitas belajar.

\section{CATATAN PENUTUP}

Pada dasarnya, bahwa pembelajaran bahasa tidak hanya memfokuskan pada spo semata tetapi linguistic funsionalpun dapat dijadikan pertimbangan. Tantangan pembelajaran bahasa Indonesia ada pada tenaga pendidik, baik sebagai tenaga pendidik BI maupun BD memiliki tantangan yang relatif sama yaitu men $\mathrm{j}$ adi pengaj ar bahasa pada penutur bahasa itu sendiri. Sebagai pengajar bahasa pada penutur bahasa itu sendiri, maka tantangan yang paling berat dihadapi adalah menghilangkan perasaan "sudah dapat menggunakan bahasa yang diajarkan itu" yang menyelimuti did pembelajar/siswa. Perasaan ini muncul sebagai akibat dari pemahaman akan fungsi bahasa sebagai sarana komunikasi.

Selain tantangan di atas, tenaga pendidik BI menghadapi pula tantangan yang tidak kalah beratnya, yaitu: (a) demam pada sesuatu yang beriabel internasional yang ditandai oleh banyaknya bermunculan SB1 yang indikatornya menggunakan bahasa pengantar bahasa asing,

(b) sikap keterjajahan yang selalu menjadi subordinat negara asing termasuk masalah pemakaian bahasa, dan (c) kedua hal itu membawa konsekunsi pada munculnya sikap negatif pada bahasa Indonesia. Adapun untuk 
tenaga pendidik BD selain tantangan di atas juga masih harus menghadapi tantangan lainnya yaitu: (a) otonomi daerah menuntut identitas kedaerahan, (b) kehendak berbagai wilayah di Indonesia memunculkan mulok bahasa daerah, (c) desakan (internasional) agar menggunakan bahasa pengantar bahasa ibu dalam pendidikan formal di Indonesia.

Untuk tenaga pendidik BI tantangan di atas sekaligus menjadi peluang untuk lebih berkreasi dalam menemukan materi dan model pembelajaran BI yang tidak hanya mengajarkan bahasa sebagai sarana komunikasi tetapi materi pembalajaran BI sebagai identitas keindonesiaan. Materi dimaksud dapat diracik dari rajutan sejarah bahasa Indonesia dalam fase pembentukan konsep kebangsaan, fase pergerakan kemerdekaan, dan fase penanaman idendtas.

Adapun untuk guru BD tantangan (b dan c) bagai gayung bersambut dengan tantangan (a), yang menuntut tanaga pendidik BD mampu mendesain pembelajaran BD yang ddak hanya bertujuan untuk pengembangan logika, etika, dan estetika, tetapi juga materi pembelajaran yang bertujuan untuk mengikis semangat etnosentris yang berlebihan. Dalam hal ini materi bahasa daerah yang berdimensi kebhinekaan dengan memanfaatkan variasi bahasa yang berkerabat.

Dalam UUD 1945 dan UU No. 20 tahun 2003 tentang Sisdiknas telah dijelaskan secara mendasar ihwal landasan filosofis yang menjadi prinsip dasar pembangunan pendidikan di Indonesia. Salah satu landasan filosofis tersebut menegaskan bahwa pendidikan pada hakikatnya merupakan upaya pemberdayaan manusia seutuhnya. Sebagai upaya pemberdayaan manusia seutuhnya, maka pendidikan menganut paradigmaa penempatan manusia sebagai subjek bukan objek pendidikan.Suatu paradigma yang memperlakukan anak sebagai manusia yang utuh, yang memiliki hak untuk mengaktualisasikan dirinya secara maksimal. Anak yang sedang mengalami pertumbuhan perlu dididik untuk dapat mengembangkan potensi dan kepribadiannya melalui bahasa. Anak ddak lagi dipaksakan untuk menurud keinginan orang tua (dalam batas-batas tertentu), sebaliknya orang tua hanya sebagai fasilitator untuk menolong anak menemukan bakat atau minatnya. Antara orang tua dengan anak atau antara guru dengan murid perlu dibangun dialog ) ${ }^{\mathrm{r}}$ ang dinamis, bukan dialog yang bersifat otoriter dan searah.

\section{DAPTAR PUSTAKA}

Anwar, Ahyar. 2008. "Bahasa Indonesia dan Realitas Indonesia".Makalah Kongres Bahasa Indonesia ke-IX, di Jakarta.

Alisjahbana, Sutan Takdir. 1981. Tatabahasa Baru Bahasa Indonesia I. Jakarta: Dian Rakyat (Cetakan pertama 1949).

Basiran, Mokh. 1999. Apakahyang Dituntut GBPP Bahasa Indonesia Kurikulum 1994?. Yogyakarta: Depdikbud

Darjowidjojo, Soenjono. 1994. Butir-butir Renungan Pengajaran Bahasa Indonesia sebagai Bahasa Asing. Makalah disajikan dalam Konferensi Internasional Pengajaran Bahasa Indonesia sebagai Bahasa Asing. Salatiga: Univeristas Kristen Satya Wacana

Degeng, I.N.S. 1997. Strategi Pembelajaran Mengorganisasi Isi dengan Model Elaborasi. Malang: IKIP dan IPTDI

Hyme, Dell. 1972. "On Communicadve Competence". Pride dan Holmes (ed.). 1972. Inhelder, B. dan J. Peaget.

Kartodirdjo, Sartono. 1993. Pengantar Sejarah Indonesia Baru: Sejarah Pergerakan Nasional dari Kolonialisme Sampai Nasionalisme. Jakarta: Gramedia Pustaka Utama 
Kaswanti Purwa, Bambang. 1990. Pragmatik dan Pengajaran Bahasa: Menyibak Kurikulum 1984. Yogyakarta: Kanisius.

Kelly, L.G. 1976. 25 Centuries of Language Teaching. Rowley (Mass.): Newbury House Publishers.

Keraf, Gorys. 1984. Tatabahasa Indonesia untuk Sekolah lanjutan Atas. Ende: Nusa Indah.

Kroskrity, Paul. 2000. Identity. Journal of Linguistic Antrophology.Volume 9(1-2).

Ricklefs, MC. 2005. Sejarah Indonesia Modern 1200-2004. Jakarta: Serambi.

Mahsun. 1998. "Pengembangan Materi Muatan Lokal yang Berdimensi Kebhinnekatunggalikaan dan Pengajarannya: Penyusunan Bahan pelajaran Bahasa Sasak dengan Memanfaatkan Variasi Bahasa yang Berkerabat (Variasi Dialektal Bahasa Sasak)". Laporan Penelitian tahun I, RUT $\mathrm{V}$, Dewan Riset Nasional.

Machfudz, Imam. 2000. Metode Pengajaran Bahasa IndonesiaKomunikatif. Jurnal Bahasa dan Sastra UM

Mahsun. 1999. "Pengembangan Materi Muatan Lokal $\mathrm{y}^{\text {an }} \mathrm{g} \quad$ Berdimensi Kebhinnekatunggalikaan dan Pengajarannya: Penyusunan Bahan pelajaran Bahasa Sasak dengan Memanfaatkan Variasi Bahasa yang
Berkerabat (Bahasa Sasak Stnadar: Kajian dari Aspek Sosiolinguistik)". Laporan Penelitian tahun II, RUT V, Dewan Riset Nasional.

Mahsun. 2010 Menggagas Pembelajaran bahasa yang bernuansa Keindonesiaan: tantangan dan peluangnya bagi tenaga pendidik bahasa dan sastra Indonesia dan daerah. Makalah disampaikan pada seminar Nasional di Palu.

Moeleong, Lexy J. 2000Metodologi Penelitian Kualitatij. Bandung: PT. Remaja Rosyda Karya.

Saksomo, Dwi. 1983. Strategi Pengajaran Bahasa Indonesia. Malang: IKIP Malang

Salamun, M. 2002J'trategi Pembelajaran Bahasa Arab di Pondok Pesantren. Tesis.. Tidak diterbitkan

Saragih, Amrin. 2010. Kontribsu linguistic Fungsional Sistemik dalam Pembangunan. Makalah disampaikan pada seminar Nasional di Palu.

Peraturan Pemerintah RI Nomor 19 Tahun 2005 tentang Standar Nasional Pendidikan

Undang-Undang Dasar 1945. Amandemen ke Empat 2002.

Undang-Undang Rl Nomor 20 Tahun 2003 tentang Sistem Pendidikan Nasional.

Undang-Undang RI Nomor 14 Tahu 2005 tentang Guru dan Dosen. 